$\Phi=$

\title{
Population and development in Uttar Pradesh: a district level analysis using census data
}

\author{
A. K. Tiwari \\ Faculty Member IBS Business School ICFAI University Dehradun India \\ E-mail: abhay_stat@rediffmail.com
}

\begin{abstract}
Population and Development is a complex area for research and it includes issues related to many variables, such as demography, economics, urbanization, gender, religion, politics, food and nutrition, health, human rights etc. The Indian census is used to collect extensive data at household level. Wide Information about source of income, information on demographic variables, household belonging, possession of various durable household goods etc. are collected in Census 2011. The present study is an attempt to analyze the population and development in Uttar Pradesh (UP), highly populated state in India. This paper will provide position of all districts of UP in respect of few selected socio- demographic variables. This study concludes that some districts of UP are performing better than many states in the country but some districts are much behind when compared with some develop states and India.
\end{abstract}

Keywords: Population; Development; Demographic and Social Variables; Census Etc.

\section{Introduction}

Uttar Pradesh generally refers as UP, is a state located in northern part of Republic of India. Earlier it was created as United Provinces in British rule however it got a name Uttar Pradesh after Independence in 1950. Lucknow is the capital of the state while Kanpur, Noida, Ghaziabad, Varanasi, Allahabad and Meerut are other main cities. UP is the most populous and $4^{\text {th }}$ largest area wise state in India. The districts of UP have been grouped in 18 divisions. The state is bordered by Rajasthan to the west, Haryana and Delhi to the northwest, Uttarakhand and the country of Nepal to the north, Bihar to the east, and Jharkhand to the southeast, Chhattisgarh to the south and Madhya Pradesh to the southwest. It has a population 199,812,341 (Census 2011). About $72.2 \%$ of the population of the state lives in rural areas. The population density is 828 which is two times more than the population density of the country 382 . The literacy rate is $77.28 \%$ for male and $51.36 \%$ for female and $67.7 \%$ for total population.

The availability of data is necessary for deriving results and making accurate decisions. Sometimes the data we need may not be available, in such cases; we may have to obtain data by conducting surveys. In survey, data is collected from the members of population or members of sample. A survey may be a Complete or Sample survey. A survey that includes a portion of the population is known as sample survey. In Complete survey, information is collected from each and every unit of the population. Population census is the process of collecting compiling and analyzing demographic and social economic data in specific period of time of all persons in a country.

The Indian census is the longest on different attributes of the people of India. The first census was conducted in 1872 and it has been conducted 15 times as of 2011. In May 1949, the Govt. of India decided to work on systematic data collection and establishment an organization the ministry of Home Affairs. The in formation collected by census are used for administration , planning and policy making by the Government, NGO etc , research in Demography, Sociology, Statistics and many other disciplines. This large scale complete survey is conducted by the office of the Registrar General and census commission under Ministry of Home Affairs, Government of India.

The present study is an attempt to analyze the population and development in UP. This paper will provide position of all districts of UP in respect of few selected socio- demographic variables.

\section{Data and methodology}

Along with the various secondary data, the census report of 2011 pertaining to UP is the primary data source of the analysis. In some cases, National Family Health Survey (NFHS) and Sample Registration System (SRS) data are also used to highlight the socio-demographic status of UP and India.

The present study follows a district wise analysis approach to know the development of districts. District - wise analysis has been done by making different groups of districts. For this study author has taken selected demographic and social variables for analysis and it has been done at district level. Selected variables are given below.

1) Literacy rate

2) Sex ratio

3) Population decadal growth rate

4) Percentage of households with electricity supply

5) Percentage of households without toilet facility

6) Percentage of households availing Banking Facility

Different groups have been made for the above mentioned variables and districts are positioned accordingly. 


\subsection{Sex ratio}

1) $\geq 1085$ (More than or equal to sex ratio of Kerala state which is the highest in India).

2) $1000-1085$ (Between sex ratio for equal number male and female and Kerala sex ratio)

3) $940-1000$ (Between sex ratio of country and sex ratio for equal number of male and female)

4) $912-940$ (Between sex ratio of UP and sex ratio of country)

5) $879-912$ (Between sex ratio of state with lowest in country and sex ratio of UP)

6) $<879$ (Less than or equal to sex ratio of state with lowest in country)

\subsection{Decadal growth rate}

1) $\leq 4.8$ (Less than or equal to growth rate of Kerala state which is the highest in India).

2) 4.8 - 15.67 (Between Kerala growth rate and growth rate of state with has achieved replacement level (Karnataka).

3) 15.67 - 17.64 (Between Karnataka growth rate and India growth rate).

4) $17.64-20.09$ (Between India growth rate and UP growth rate).

5) $20.09-25.07$ (Between UP growth rate and growth rate of Bihar the state with highest growth rate (Bihar).

6) $>25.07$ (More than or equal to Bihar growth rate).

\subsection{Literacy rate}

1) $\geq 94$ (More than or equal to literacy rate of Kerala state which is highest in India.

2) 74.04 - 94 (Between literacy rate of India and literacy rate of Kerala).

3) 67.7 - 74.04 (Between UP Literacy rate and India literacy rate).

4) $63.82-67.7$ (Between Bihar literacy rate and UP literacy rate).

5) $\leq 63.8$ (Less than or equal to Bihar literacy rate).

\subsection{Electricity supply percentage}

1) $\geq 96.60$ (Higher than or equal to electricity supply percentage of Punjab the state which is highest in India).

2) $67.25-96.60$ (Between electricity supply percentage of India and electricity supply percentage of Punjab).

3) $36.81-67.25$ (Between UP electricity supply and India electricity supply).

4) 16.36 - 36.81 (Between Bihar electricity supply and UP electricity supply).

$5) \leq 16.36$ (Electricity supply less than country's worst state i.e Bihar).

\subsection{Without toilet facility}

1) $\leq 4.8$ (Less than or equal to without toilet facility percentage of Kerala the state which is lowest in country).

2) $4.8-53.08$ (Between without having toilet percentage of Kerala and India).

3) $53.08-64.35$ (Between without having toilet percentage India and UP).

4) $64.35-77.97$ (Between without having toilet facility percentage UP and Orissa the state which is nation worst).

5 ) $\geq 77.97$ (Not having toilet facility percentage is higher than nation worst state Orissa).

\subsection{Households availing banking services}

1) $\geq 89.12$ (Higher than or equal to percentage of households availing banking services as compare to HP the state which is highest in country).

2) 58.69 - 89.12 (Percentage of households availing banking services between India and HP).

$3) \leq 58.69$ Percentage of households which has less than or equal to India.

\section{Results}

The selected demographic characteristics of the population in UP and India from 1991 to 2011 are given in the table 1.The population of UP increased more than 1.43 times from 1981 (Uttarakhand included) to 2011. Above table shows decadal growth rate of population has declined from $25.6 \%$ during 1981 - 1991 to 20012011. Percentage during $2001-2011$ for UP and for India it has declined from 1991 to 2011 for both UP and India. The census 2011 experienced a decrease in the child sex ratio from 927 in 1991 to 902 in 2011 . It can be seen from the table 1 that literacy rate has been increased for both UP and India. Table indicates improvement in Infant mortality rate and total fertility rate.

UP is one of the few states registering an upward trend in population sex ratio during the last decade but downward trend was found in child sex ratio, except three eastern districts Azamgarh, Jaunpur and Deoria in state all districts have more numbers of males than females. Author has made different groups of districts on the basis of sex ratio. No Districts of UP has sex ratio like Kerala and only three districts have sex ratio more than 1000 . Table 3 shows that only fourteen districts of UP have sex ratio between national sex ratio and sex ratio for equal number of male and female. Sixty five percent districts have sex ratio less than sex ratio of UP. It is very dangerous situation for 10 districts of UP almost situated in western part of the state, which have sex ratio less than Haryana sex ratio.

The Literacy rate is a very good measure of the education standard and achievement of a society. UP had a literacy rate of only 12 percent against India's $18 \%$ in 1951 . The literacy rate in UP has improved from $56.3 \%$ in 2001 to $67.7 \%$ in 2011. No state of India has $100 \%$ literacy rate. All districts have been divided in five groups. Literacy rate of all districts of UP is lesser than literacy rate of Kerala. Only ten districts have literacy rate between literacy rates of India and UP. Table 4 indicates that literacy rate of seventeen districts is lesser than literacy rate of Bihar.

The decadal growth rate during the period 2001-2011 in case of UP was $20 \%$ which is higher than the country growth rate $17.64 \%$. Author has divided all 71 districts of UP by using decadal growth rate of Kerala, Karnataka, India and UP and Bihar. One district of UP had negative decadal growth rate. Population growth rates of ten districts of UP lie between growth rate of Kerala and Karnataka. Thirteen districts have decadal growth rate between growth rate of Karnataka and India. Table 5 reveals that more than $50 \%$ of districts have population decadal growth rate less than UP decadal growth rate. Table also shows that ten districts have more than Bihar decadal growth rate.

UP is one of the states in India with worst condition of Electricity supply. In India the highest percentage of electricity supply state is Punjab and there is no district of UP which come closer to the percentage of Punjab. There are seven districts in state which comes under the electricity supply \% of Punjab (96.60\%) to electricity supply $\%$ of India $(67.25 \%)$. There are 18 districts in UP fall under electricity supply of UP $(36.81 \%)$ and India (67.25\%). More than $50 \%$ of districts 39 districts are between the electricity supply of the Bihar (16.36\%) and UP itself which is (36.81\%). This is the dangerous situation of India and UP that after 67 Years of Independence we have to see this horrible data. The situation is more than worst in 7 districts of UP where the percentage of electricity supply is lower than the electricity supply of Bihar $(16.36 \%)$. 
UP is one of the states in India with maximum no of households without toilet facility. There is no district in UP which not having toilet facility percentage less than Kerala which has India's best percentage $(4.8 \%)$. There are fourteen districts which fall under the not having toilet facility percentage between Kerala $(4.8 \%)$ and India $(53.08 \%)$. The nine districts are under the percentage between India $(53.08 \%)$ and UP itself $(64.35 \%)$. Twenty five districts of UP have fall under the percentage of UP (64.35\%) and Nations worst Orissa $(77.97 \%)$. Shockingly there are 21 districts in UP which have percentage of households which are not having toilet facility is higher than Nations worst Orissa (77.97\%).

In UP the total percentage of household which are not using kitchen facility is almost same as like toilet facility. UP is really lacking behind in terms of basic needs and basic infrastructure. There is no district in UP which not having Kitchen facility percentage less than Kerala which has India's best percentage (1.53\%). There are three districts which fall under the not having Kitchen facility percentage between Kerala (1.53\%) and India (31.54\%). 31 districts are come under the percentage between India $(31.54 \%)$ and UP itself (53.82\%). There are 3districts of UP have fall under the percentage of UP $(53.82 \%)$ and Nations worst Orissa $(57.45 \%)$. There are 35 districts in UP which have percentage of households which are not having Kitchen facility is higher than Nations worst Bihar (57.45\%).

This table indicates the total no of households in every district of UP which are availing Banking facilities and this is something where we can have a smile on UP. There is no district in UP with the percentage of household availing Banking services more than National best HP (89.12\%), However, there are 69 districts of UP which are come under the percentage of India (58.69\%) and national best HP $(89.12 \%)$.

There are only 2 districts of UP which are total no of household availing banking facilities lower than India (58.69\%).

\section{Conclusion and policy implications}

The present paper analyses the population and development of UP at district level.

Though the demographic and Family welfare related indicators for the population of UP are relatively poor than India. Some districts of UP are better than many states in the country but some districts are much behind when compared with some develop states and India.

In India in recent decades commendable infrastructure is created for providing school education in the districts. This study shows that more percentage of districts seek more attention for improving the literacy level. The population belongs to seventeen districts which have lower level of literacy and their literacy rate is less than Bihar literacy rate.

The population of Uttarakhand has increased and very wide interdistricts variation in population growth was observed in census 2011. Only few districts of UP have achieved the replacement level of Fertility. Above analyses shows that population growth of ten districts of UP is more than the population growth of state wise highest growth rate of population.

The majority of the districts are in UP present challenges for sex ratio. Figure of only three districts show in favor for female. In this analysis very dangerous position was seen in nineteen districts of UP. All districts have sex ratio less than Haryana. Recently Beti bachao, beti padhao' scheme was launched by PM Shri Narendra Modi. It will focus on a multi-sectoral approach to tackling the problem of the vanishing girl child.

The analyses indicate many areas that need intervention in electricity supply. Electricity is a problem in UP as more than $80 \%$ of districts. The analysis also concludes performance is very poor in respect of having kitchen and toilet facility. In UP availing banking facility better some states as well as India.

Table 1: Demographic Characteristics of Uttar Pradesh and India

\begin{tabular}{|c|c|c|c|c|c|c|}
\hline \multirow{2}{*}{ Characteristics } & \multicolumn{3}{|l|}{ Uttar Pradesh } & \multicolumn{3}{|l|}{ INDIA } \\
\hline & 1991 & 2001 & 2011 & 1001 & 2001 & 2011 \\
\hline Total Population & 139112287 & 166107021 & 100812341 & 846302688 & 1078737436 & רינ 103 ח10 \\
\hline 0 -6 Ponulation & & & & & & \\
\hline $0-6$ Population & 28200000 & $31,624,000$ & $29,728,060$ & 150421000 & $16,38,37,395$ & $15,87,89,287$ \\
\hline Total Sex Ratio & 859 & 898 & 912 & 927 & 933 & 940 \\
\hline $0-6$ Sex Ratio & 927 & 942 & 902 & 945 & 927 & 914 \\
\hline Decadal Growth & $25.6 \%$ & $25.8 \%$ & $20.1 \%$ & $23.87 \%$ & $21.54 \%$ & $17.64 \%$ \\
\hline Literacy Rate & $40.7 \%$ & $56.3 \%$ & $67.7 \%$ & $52.21 \%$ & $65.38 \%$ & $74.04 \%$ \\
\hline Population Density & $548 / \mathrm{Km} 2$ & $689 / \mathrm{Km} 2$ & $828 / \mathrm{Km} 2$ & $267 / \mathrm{Km} 2$ & $324 / \mathrm{Km} 2$ & $382 / \mathrm{Km} 2$ \\
\hline IMR & & 77 & 57 & 75 & 66 & 44 \\
\hline TFR & & 4.5 & 3.4 & 3.3 & 2.9 & 2.4 \\
\hline CBR & 35.7 & 32.1 & 27.8 & 29.5 & 23.1 & 21.8 \\
\hline
\end{tabular}

Table 2: Characteristics of All Districts of Uttar Pradesh

\begin{tabular}{|c|c|c|c|c|c|c|c|}
\hline Districts & $\begin{array}{l}\text { Total Popu- } \\
\text { lation }\end{array}$ & $\begin{array}{l}\text { Sex } \\
\text { Ratio }\end{array}$ & $\begin{array}{l}\text { Literacy } \\
\text { Rate }\end{array}$ & $\begin{array}{l}\text { Households \% } \\
\text { without Elec- } \\
\text { tricity }\end{array}$ & $\begin{array}{l}\text { Households\% } \\
\text { without Toilet } \\
\text { Facility }\end{array}$ & $\begin{array}{l}\text { Households\% } \\
\text { without Kitchen }\end{array}$ & $\begin{array}{l}\text { Total \% of house- } \\
\text { holds availing } \\
\text { banking services }\end{array}$ \\
\hline Allahabad & $5,959,798$ & 901 & $72.32 \%$ & 56.4 & 69 & 39.3 & 73 \\
\hline Moradabad & $4,773,138$ & 906 & $56.77 \%$ & 64 & 36.8 & 48.4 & 66 \\
\hline Ghaziabad & $4,661,452$ & 881 & 78.07 & 16.3 & 15.4 & 28.4 & 68.8 \\
\hline Azamgarh & $4,616,509$ & 1019 & $70.93 \%$ & 72.2 & 79.5 & 52.2 & 80.9 \\
\hline Lucknow & $4,588,455$ & 917 & $77.29 \%$ & 29.1 & 34.4 & 35.3 & 74.7 \\
\hline Kanpur Nagar & $4,572,951$ & 862 & $79.65 \%$ & 36.9 & 36.7 & 39 & 74 \\
\hline Jaunpur & $4,476,072$ & 1024 & $71.55 \%$ & 72.8 & 80.2 & 36.1 & 82.2 \\
\hline Sitapur & $4,474,446$ & 888 & $61.12 \%$ & 87.1 & 81.7 & 74.6 & 78.7 \\
\hline Bareilly & $4,465,344$ & 887 & $58.49 \%$ & 63.3 & 38 & 53.2 & 65.9 \\
\hline Gorakhpur & $4,436,275$ & 950 & $70.83 \%$ & 57.4 & 69.3 & 50.9 & 79.4 \\
\hline Agra & $4,380,793$ & 868 & $71.58 \%$ & 20.2 & 53.7 & 49.8 & 65.4 \\
\hline Muzaffarnagar & $4,138,605$ & 889 & $69.12 \%$ & 45.9 & 34 & 42.1 & 65.4 \\
\hline Hardoi & $4,091,380$ & 868 & $64.57 \%$ & 86.5 & 75.5 & 74.7 & 68 \\
\hline Kheri & $4,013,634$ & 894 & $60.56 \%$ & 82.7 & 75.2 & 73.6 & 79.9 \\
\hline Sultanpur & $3,790,922$ & 983 & $69.27 \%$ & 62.7 & 83.8 & 51.8 & 79.2 \\
\hline Bijnor & $3,683,896$ & 917 & $68.48 \%$ & 57.3 & 39.5 & 37.8 & 73.7 \\
\hline Budaun & $3,712,738$ & 871 & $52.91 \%$ & 81.9 & 68.8 & 70.6 & 47.5 \\
\hline Varanasi & $3,682,194$ & 913 & $75.60 \%$ & 38 & 45.5 & 27.6 & 74.5 \\
\hline Aligarh & $3,673,849$ & 882 & $67.52 \%$ & 55.6 & 58 & 59 & 64.1 \\
\hline Ghazipur & $3,622,727$ & 952 & $71.78 \%$ & 79.9 & 77.9 & 51.6 & 77.1 \\
\hline
\end{tabular}




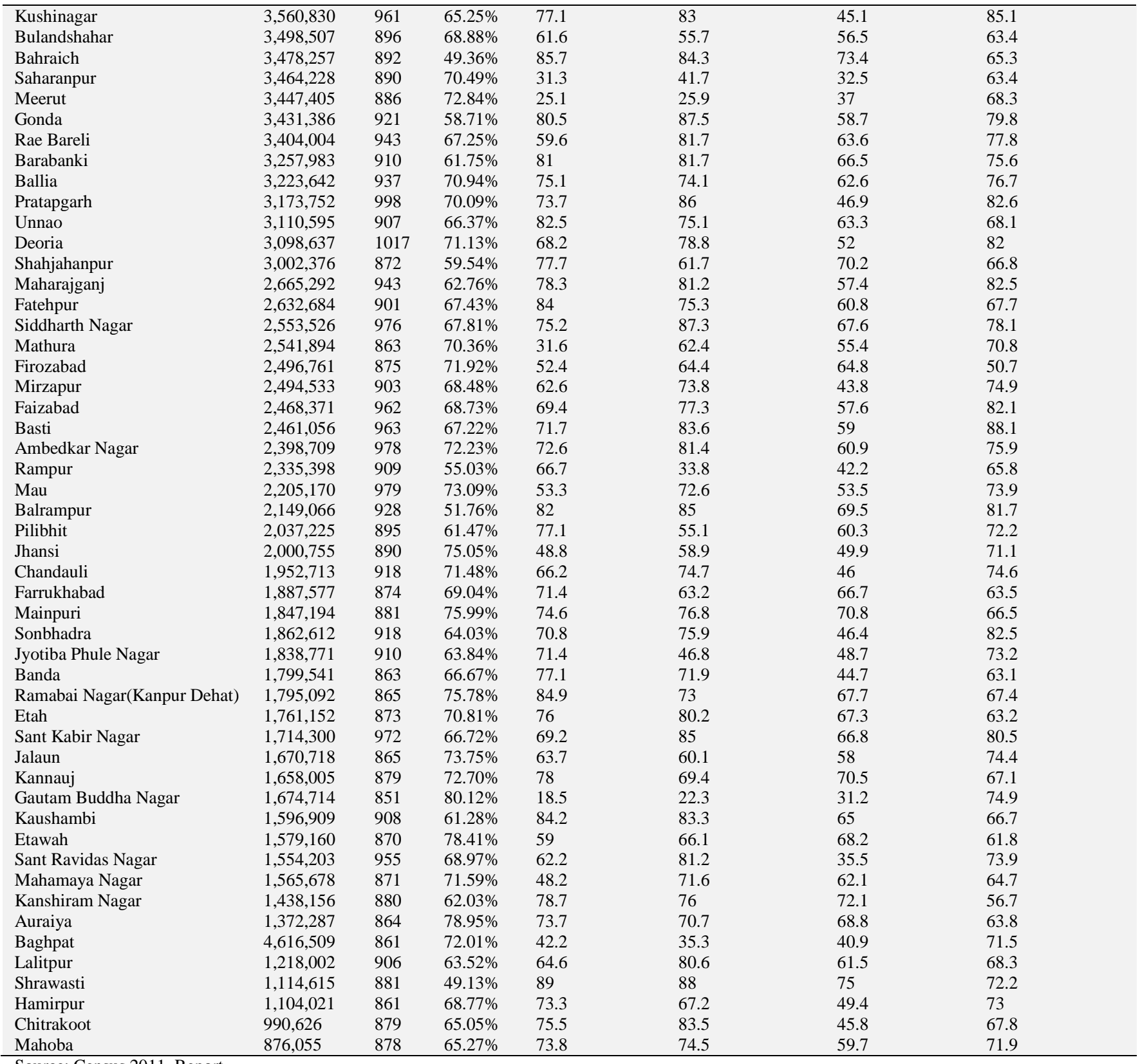

Source: Census 2011, Report.

Table 3: Distribution of Districts in Different Categories of Sex Ratio

\begin{tabular}{|c|c|c|c|c|}
\hline $\begin{array}{l}\text { S. } \\
\text { No. }\end{array}$ & $\begin{array}{l}\text { Different cate- } \\
\text { gories of sex } \\
\text { ratio }\end{array}$ & $\begin{array}{l}\text { No. of } \\
\text { Districts }\end{array}$ & Name of Districts & $\begin{array}{l}\text { Percentage of } \\
\text { population }\end{array}$ \\
\hline 1. & $\geq 1084$ & 0 & Not Available (NA) & 0 \\
\hline 2. & $1000-1084$ & 3 & Azamgarh, Jaunpur and Deoria & 6.1 \\
\hline 3 & 940- 1000 & 14 & $\begin{array}{l}\text { Gorakhpur, Sultanpur, Ghazipur, Kushinagar, Rae Bareli, Pratapgarh, Maharajganj, Siddharth } \\
\text { Nagar, Faizabad, Basti, Ambedkar Nagar, Mau, Sant Kabir Nagar and Sant Ravidas Nagar. }\end{array}$ & 19.0 \\
\hline 4. & $912-940$ & 8 & $\begin{array}{l}\text { Lucknow, Bijnor, Varanasi, Gonda, Ballia, Balrampur, Chandauli and Sonbhadra. } \\
\text { Allahabad, Moradabad, Ghaziabad, Sitapur, Bareilly, Muzaffarnagar, Kheri, Aligarh, Buland- }\end{array}$ & 12.3 \\
\hline 5. & $879-912$ & 27 & $\begin{array}{l}\text { shahar, Bahraich, Saharanpur, Meerut, Barabanki, Unnao, Fatehpur, Mirzapur, Rampur, } \\
\text { Pilibhit, Jhansi, Mainpuri, Jyotiba Phule Nagar, Kannauj, Kaushambi, Kanshiram Nagar, Lalit- } \\
\text { pur, Shrawasti and Chitrakoot. }\end{array}$ & 39.8 \\
\hline 6. & $\leq 879$ & 19 & $\begin{array}{l}\text { Kanpur Nagar, Agra, Hardoi, Budaun, Shahjahanpur, Mathura, Firozabad, Farrukhabad, Ban- } \\
\text { da, Ramabai Nagar, Etah, Jalaun, Gautam Buddha Nagar, Etawah, Mahamaya Nagar, Auraiya, } \\
\text { Baghpat, Hamirpur and Mahoba. }\end{array}$ & 23.3 \\
\hline
\end{tabular}


Table 4: Distribution of Districts in Different Categories of Literacy Rate

\begin{tabular}{|c|c|c|c|c|}
\hline $\begin{array}{l}\text { S. } \\
\text { No. }\end{array}$ & $\begin{array}{l}\text { Different cate- } \\
\text { gories of litera- } \\
\text { cy rate }\end{array}$ & $\begin{array}{l}\text { No. of } \\
\text { Districts }\end{array}$ & Name of Districts & $\begin{array}{l}\text { Percentage of } \\
\text { population }\end{array}$ \\
\hline 1. & $\geq 94$ & 0 & NA & 0 \\
\hline 2. & $74.04-94$ & 10 & $\begin{array}{l}\text { Ghaziabad, Lucknow, Kanpur Nagar, Varanasi, Jhansi, Mainpuri, Ramabai Nagar, Gautam } \\
\text { Buddha Nagar, Etawah and Auraiya. }\end{array}$ & 13.7 \\
\hline 3. & $67.7-74.04$ & 31 & $\begin{array}{l}\text { Allahabad, Azamgarh, Jaunpur, Gorakhpur, Agra, Muzaffarnagar, Sultanpur, Bijnor, Ghazipur, } \\
\text { Bulandshahar, Saharanpur, Meerut, Ballia, Pratapgarh, Deoria, Mathura, Firozabad, Mirzapur, } \\
\text { Faizabad, Ambedkar Nagar, Mau, Chandauli, Etah, Jalaun, Kannauj, Mahamaya Nagar, } \\
\text { Baghpat, Sant Ravidas Nagar, Hamirpur, Farrukhabad and Siddharth Nagar. }\end{array}$ & 46.3 \\
\hline 4. & $63.82-67.7$ & 13 & $\begin{array}{l}\text { Hardoi, Aligarh, Kushinagar, Rae Bareli, Unnao, Fatehpur, Basti, Sonbhadra, Jyotiba Phule } \\
\text { Nagar, Banda, Sant Kabir Nagar, Chitrakoot and Mahoba. }\end{array}$ & 15.8 \\
\hline 5. & $\leq 67.7$ & 17 & $\begin{array}{l}\text { Moradabad, Sitapur, Bareilly, Kheri, Budaun, Bahraich, Gonda, Barabanki, Shahjahanpur, } \\
\text { Maharajganj, Rampur, Balrampur, Pilibhit, Kaushambi, Kanshiram Nagar, Lalitpur and } \\
\text { Shrawasti. }\end{array}$ & 24.2 \\
\hline
\end{tabular}

Table 5: Distribution of Districts in Different Categories of Decadal Growth Rate

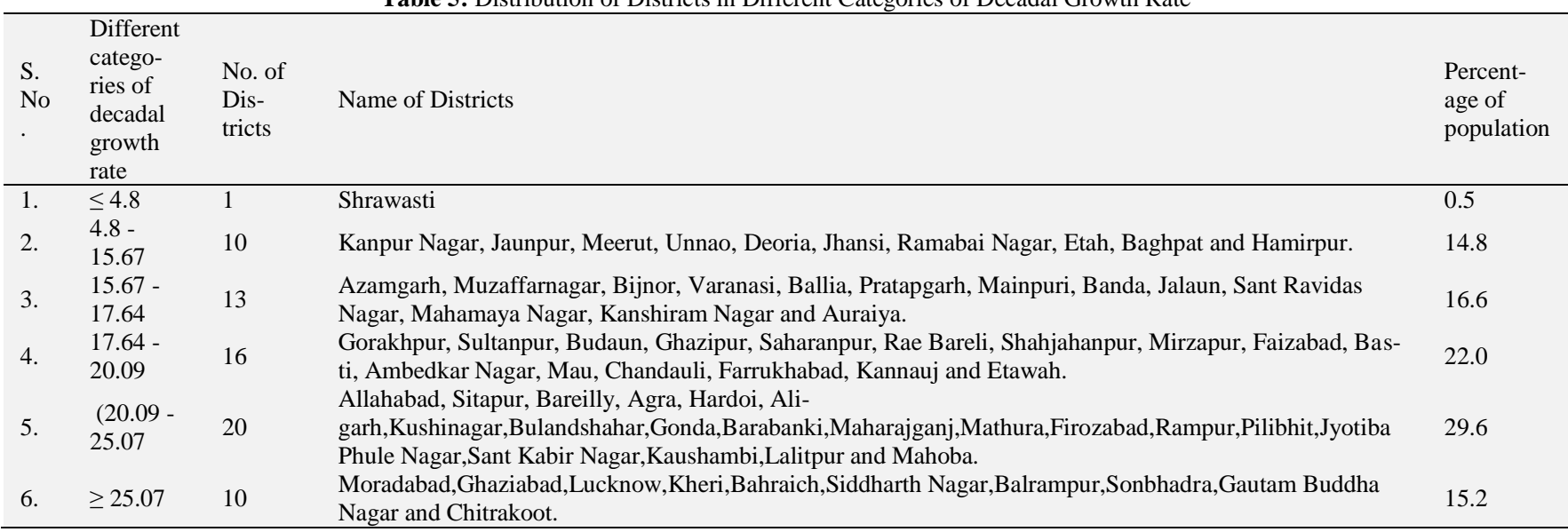

Table 6: Distribution of Districts in Different Categories of Electricity Supply

\begin{tabular}{|c|c|c|c|c|}
\hline $\begin{array}{l}\text { S. } \\
\text { No. }\end{array}$ & $\begin{array}{l}\text { Different } \\
\text { categories } \\
\text { of Electrici- } \\
\text { ty Supply }\end{array}$ & No. of Districts & Name of Districts & $\begin{array}{l}\text { Percentage } \\
\text { of popula- } \\
\text { tion }\end{array}$ \\
\hline 1. & $\geq 96.60 \%$ & 0 & NA & 0 \\
\hline 2. & $\begin{array}{l}67.25 \%- \\
96.60 \%\end{array}$ & 7 & Ghaziabad,Lucknow,Agra,Saharanpur,MeerutMathura and Gautam Buddha Nagar & 12.2 \\
\hline 3. & $\begin{array}{l}36.81 \%- \\
67.25 \%\end{array}$ & 18 & $\begin{array}{l}\text { Allaha- } \\
\text { bad,KanpurNagar,Gorakhpur,Muzaffarnagar,Sultanpur,Bijnor,Aligarh,Bulandshahar,RaeB } \\
\text { areli,Firozabad,Mirzapur,Mau,Jhansi,Sant RavidasNagar,Mahamaya Na- } \\
\text { gar,Baghpat,Varanasi and Etawah. }\end{array}$ & 29.3 \\
\hline 4. & $\begin{array}{l}16.36 \%- \\
36.81 \%\end{array}$ & 39 & $\begin{array}{l}\text { Morada- } \\
\text { bad,Azamgarh,Jaunpur,Bareilly,Kheri,Budaun,Ghazipur,Kushinagar,Gonda,Barabanki,Ball } \\
\text { ia,Pratapgarh,Unnao,Deoria,Shahjahanpur,Maharajganj,SiddharthNagar,Faizabad,Basti,Am } \\
\text { bedkarNa- } \\
\text { gar,Rampur,Balrampur,Pilibhit,Chandauli,Farrukhabad,Mainpuri,Sonbhadra,Jyotiba Phule } \\
\text { Nagar,Banda,Etah,Sant Kabir Nagar,Jalaun,Kannauj,Kanshiram Na- } \\
\text { gar,Auraiya,Lalitpur,Hamirpur,Chitrakoot,Mahoba. }\end{array}$ & 49.1 \\
\hline
\end{tabular}

Table 7: Distribution of Districts in Different Categories of Toilet Facility.

\begin{tabular}{|c|c|c|c|c|}
\hline $\begin{array}{l}\text { S. } \\
\text { N } \\
\text { o. }\end{array}$ & $\begin{array}{l}\text { Different categories } \\
\text { of Toilet Facility }\end{array}$ & $\begin{array}{l}\text { No. of } \\
\text { Districts }\end{array}$ & Name of Districts & $\begin{array}{l}\text { Percentage } \\
\text { of popula- } \\
\text { tion }\end{array}$ \\
\hline 1. & $\leq 4.8 \%$ & 0 & NA & 0 \\
\hline 2. & $4.8 \%-53.08 \%$ & 14 & $\begin{array}{l}\text { Morada- } \\
\text { bad,Lucknow,Kanpur,Nagar,Bareilly,Muzaffarnagar,Bijnor,Varanasi,Saharanpur,Meerut,Ra } \\
\text { mpur,Jyotiba Phule Nagar,Gautam Buddha Nagar and Baghpat. }\end{array}$ & 29.4 \\
\hline 3. & $53.08 \%-64.35 \%$ & 9 & $\begin{array}{l}\text { Agra, Aligarh, Bulandshahar, Shahjahanpur, Mathura, Pilibhit, Jhansi, Farrukhabad and Ja- } \\
\text { laun. }\end{array}$ & 12.2 \\
\hline 4. & $64.35 \%-77.97 \%$ & 25 & $\begin{array}{l}\text { Allaha- } \\
\text { bad,Gorakhpur,Hardoi,Kheri,Budaun,Ghazipur,Ballia,Unnao,Fatehpur,Firozabad,Mirzapur,F } \\
\text { aizabad,Mau,Chandauli,Mainpuri,Sonbhadra,Banda,Ramabai Na- } \\
\text { gar(Dehat),Kannauj,Etawah,Mahamaya Nagar,Kanshiram Nagar,Auraiya,Hamirpur and } \\
\text { Mahoba. }\end{array}$ & 31.2 \\
\hline 5. & $\geq 77.97 \%$ & 21 & $\begin{array}{l}\text { Jaun- } \\
\text { pur,Sitapur,Sultanpur,Kushinagar,Bahraich,Gonda,Rae,Bareli,Barabanki,Pratapgarh,Maharaj } \\
\text { ganj,Siddharth Nagar,Basti,Ambedkar Nagar,Balrampur,Etah,Sant,Kabir Na- } \\
\text { gar,Kaushambi,Sant Ravidas Nagar,Lalitpur,Shrawasti and Chitrakoot. }\end{array}$ & 27.2 \\
\hline
\end{tabular}


Table 8: Distribution of Districts in Different Categories of Kitchen Facility.

\begin{tabular}{|c|c|c|c|c|}
\hline $\begin{array}{l}\text { S. } \\
\text { No. }\end{array}$ & $\begin{array}{l}\text { Different categories of } \\
\text { Kitchen Facility }\end{array}$ & No. of Districts & Name of Districts & $\begin{array}{l}\text { Percentage } \\
\text { of popula- } \\
\text { tion }\end{array}$ \\
\hline 1. & $\leq 1.53 \%$ & 0 & NA & 0 \\
\hline 2. & $1.53 \%-31.54 \%$ & 3 & $\begin{array}{l}\text { Ghaziabad, Varanasi and Gautam Buddha Nagar. } \\
\text { Allaha- } \\
\text { bad,Moradabad,Azamgarh,Lucknow,Kanpur,Nagar,Jaunpur,Bareilly,Gorakhpur }\end{array}$ & 4.9 \\
\hline 3. & $31.54 \%-53.82 \%$ & 31 & $\begin{array}{l}\text {,Pratapgarh,Deoria,Mirzapur,Rampur,Mau,Jhansi,Chandauli,Sonbhadra,Jyotiba } \\
\text { Phule Nagar,Banda, Sant Ravidas Nagar, Baghpat,Hamirpur and Chitrakoot. }\end{array}$ & 48.8 \\
\hline 4. & $53.82 \%-57.45 \%$ & 3 & $\begin{array}{l}\text { Bulandshahar, Shahjahanpur and Mathura. } \\
\text { Sita- } \\
\text { pur,Hardoi,Kheri,Budaun,Aligarh,Bahraich,Gonda,Rae,Bareli,Barabanki,Ballia, } \\
\text { Un- }\end{array}$ & 4.5 \\
\hline 5. & $\geq 57.45 \%$ & 35 & $\begin{array}{l}\text { nao,Shahjahanpur,Fatehpur,Siddharth,Nagar,Firozabad,Faizabad,Basti,Ambedk } \\
\text { ar,Nagar,Balrampur,Pilibhit,Farrukhabad,Mainpuri,Ramabai,N,gar(Kanpur } \\
\text { Dehat),Etah,SantKabir,Nagar,Jalaun,Kannauj,Kaushambi,Etawah,Mahamaya,N } \\
\text { agar,Kanshiram,Nagar,Auraiya,Lalitpur,Shrawasti and Mahoba. }\end{array}$ & 41.8 \\
\hline
\end{tabular}

Table 9: Distributions of Districts in Different Categories of Availing Banking Facility.

\begin{tabular}{llll}
\hline S. No. $\quad \begin{array}{l}\text { Different categories of Availing } \\
\text { Banking Facility }\end{array}$ & $\begin{array}{l}\text { No. of Dis- } \\
\text { tricts }\end{array}$ & Name of Districts \\
\hline $89.12 \%$. & 0 & $\begin{array}{l}\text { NA } \\
\text { Allahabad,Moradabad,Ghaziabad,Azamgarh,Lucknow,Kanpur Na- } \\
\text { gar,Jaunpur,Sitapur,Bareilly,Gorakhpur,Agra,Muzaffarnagar,Hardoi,Kheri,Sultanpur,Bij } \\
\text { nor,Varanasi,Aligarh,Ghazipur,Kushinagar,Bulandshahar,Bahraich,Saharanpur,Meerut, } \\
\text { Gonda,Rae }\end{array}$ \\
& & $\begin{array}{l}\text { Bareli,Barabanki,Ballia,Pratapgarh,Unnao,Deoria,Shahjahanpur,Maharajganj,Fatehpur,S } \\
\text { iddharth Nagar,Mathura,Firozabad,Mirzapur,Faizabad,Basti,Ambedkar Na- } \\
\text { gar,Rampur,Mau,Balrampur,Pilibhit,Jhansi,Chandauli,Farrukhabad,Mainpuri,Sonbhadra } \\
58.69 \%-89.12 \% .\end{array}$ & $\begin{array}{l}\text { Jyotiba Phule Nagar,Banda,Ramabai Nagar(Kanpur Dehat),Etah,Sant Kabir Na- } \\
\text { gar,Jalaun,Kannauj,Gautam Buddha Nagar,Kaushambi,Etawah,Sant Ravidas Na- } \\
\text { gar,Mahamaya Nagar,Auraiya,Baghpat,Lalitpur,Shrawasti,Hamirpur,Chitrakoot } \\
\text { andMahoba. } \\
\text { Budaun and Kanshiram Nagar. }\end{array}$ \\
& & 2 & \\
\hline $58.69 \%$ & &
\end{tabular}

\section{References}

[1] International Institute for Population Sciences IIPS (2007). National Family Health Survey, 2005-06. Mumbai: IIPS and ORC Macro.

[2] Office of the Registrar General of India (2011): Census of India New Delhi, Government of India.

[3] Office of the Registrar General of India (2001): Census of India, New Delhi, Government of India. 